\title{
Goliath grouper Epinephelus itajara sound production and movement patterns on aggregation sites
}

\author{
David A. Mann ${ }^{1, *}$, James V. Locascio ${ }^{1}$, Felicia C. Coleman ${ }^{2}$, Christopher C. Koenig ${ }^{2}$ \\ ${ }^{1}$ University of South Florida, College of Marine Science, 1407 th Avenue South, St. Petersburg, Florida 33701, USA \\ ${ }^{2}$ Florida State University Coastal and Marine Laboratory, 3618 Highway 98, St. Teresa Beach, Florida 32358, USA
}

\begin{abstract}
Sound production by goliath grouper Epinephelus itajara was characterized on 2 aggregation sites in the Gulf of Mexico off the southwest coast of Florida, which are likely to be spawning sites, based on the presence of fish with ripe gonads. Goliath grouper produced predominately lowfrequency single-pulse sounds with dominant frequencies around $60 \mathrm{~Hz}$. Long-term acoustic recordings documented that sounds were most frequently produced between 01:00 and 03:00 h. Sound production had a lunar periodicity, with reduced levels occurring for several days around the full moon. A single goliath grouper was implanted with an acoustic telemetry transmitter that indicated the depth of the fish. This fish remained on the aggregation site for all but $1 \mathrm{~d}$ of the 2 mo record and was located near the bottom $(46 \mathrm{~m})$ for the majority of the time. Several forays to shallower depths were detected, most of which occurred near midnight and 03:00 h. These short-duration shallow-water forays could possibly indicate spawning ascents. The combination of passive acoustics and active acoustic telemetry indicates that efforts to document spawning should be concentrated around midnight. The prolific sound production of goliath grouper will allow large spatial and temporal scale mapping and monitoring of aggregation sites.
\end{abstract}

KEY WORDS: Goliath grouper - Epinephelus itajara - Sound production - Passive acoustics · Fish tracking $\cdot$ Depth distribution $\cdot$ Spawning aggregations

\section{INTRODUCTION}

Many fishes produce species-specific sounds in a variety of behavioral contexts (Fish \& Mowbray 1970, Tavolga 1977, Saucier et al. 1992, Gilmore 2003, Amorim 2006, Ladich \& Myrberg 2006). Intentionally produced sounds are typically associated with courtship and spawning behavior and/or agonistic behavior. In the case of sciaenids (drums), it has been well documented that patterns of sound production and sonic muscle mass coincide with seasonal periods of spawning, and so data from hydrophone recordings can serve as a useful proxy for spawning activity (Mok \& Gilmore 1983, Connaughton \& Taylor 1995, Mann \& Lobel 1995, Hood et al. 1999, Locascio \& Mann 2008). High temporal resolution data collected with a Long-Term
Acoustic Recording System (LARS) over 34 consecutive days in Charlotte Harbor, Florida demonstrated marked diel periodicity in sound production by an aggregation of sand seatrout Cynoscion arenarius during the peak of the spawning season (Locascio \& Mann 2008). Although not as well documented as the sciaenids, sound production by serranids (sea basses) has been previously documented for Nassau grouper Epinephelus striatus (Hazlett \& Winn 1962), goliath grouper, (Fish \& Mowbray 1970), and hamletfish Hypoplectrus spp. (Lobel 1992). Colin (1990) also describes sound produced by goliath grouper on a wreck in the eastern Gulf of Mexico consisting of loud low-frequency booms easily heard by divers. One presumed male was observed to boom during presumed courtship behavior as it swam up alongside goliath 
grouper that were thought to be female (Colin 1990). To our knowledge, spawning has not been observed in this species.

Goliath grouper form aggregations on reefs and shipwrecks where they are suspected to spawn (Sadovy \& Eklund 1999, SEDAR6 2004) during June through December, with peak spawning activity occurring from July through September in the eastern Gulf of Mexico (Bullock et al. 1992). While tagging studies have demonstrated site fidelity at such locations (Koenig et al. 2007), it is unclear whether spawning migrations to certain key sites bring larger numbers of goliath grouper together from a broader area, as has been documented for a variety of grouper species (e.g. Sadovy 1994). The Southeast Data Assessment and Review 6 workshop (SEDAR6 2004) highlighted the identification of spawning locations, duration and periodicity of goliath grouper as important research needs.

Goliath grouper is critically endangered over its entire range (Chan Tak-Chuen \& Padovani Ferreira 2006), which extends from west Africa to the Pacific coast of Central America, south to Brazil and north to North Carolina. The species has been fully protected in the southeastern USA since the early 1990s, and is showing strong signs of recovery, especially in southwest Florida, where the present study was conducted. Key factors in recovery include extensive high quality mangrove nursery habitat in that area (Koenig et al. 2007) and an abundance of presumed spawning aggregation sites on the southwest Florida shelf (C. C. Koenig unpubl. data). Identification and verification of spawning aggregation sites is important to the conservation of the species, but spawning has not been verified and little is known of the temporal and spatial aspects of spawning.

The purpose of the present study was to record sound production by goliath grouper during the spawning season at 2 aggregation sites in the Gulf of Mexico, where spawning is suspected to occur, based on the occurrence of adults with ripe gonads. Longterm acoustic recorders were used to document the timing of goliath grouper sound production during the fall spawning season (Bullock et. al 1992, C. C. Koenig unpubl. data). At 1 site an acoustic transmitter was implanted in a goliath grouper to record information on site fidelity and patterns of movement within the water column.

\section{MATERIALS AND METHODS}

Study sites. Studies of goliath grouper were made at 2 aggregation sites off the Florida Gulf coast during the spawning season in late summer and fall. Passive acoustic recordings and studies with a depth-indicating acoustic transmitter were conducted near the Dry Tortugas $\left(24^{\circ} 45.9^{\prime} \mathrm{N}, 82^{\circ} 59.4^{\prime} \mathrm{W}\right.$; bottom depth $\left.=46 \mathrm{~m}\right)$ in September and October 2005. Passive acoustic recordings were also made on a wreck on the southwest coast of Florida north of the Dry Tortugas $\left(26^{\circ} 17.7^{\prime} \mathrm{N}\right.$, $82^{\circ} 50^{\prime} \mathrm{W}$; bottom depth $=34 \mathrm{~m}$ ) from July 29 to December 21, 2007. This site will be referred to as the Northern Site.

Passive acoustic recordings. Passive acoustic recordings were made with an underwater LARS (Loggerhead Instruments) consisting of a Toshiba Pocket PC in an underwater housing connected to a hydrophone (HTI96-min; High-Tech; sensitivity -164 dBV/ $\mu \mathrm{Pa}, 2 \mathrm{~Hz}$ to $37 \mathrm{kHz}$ ). The acoustic signals were digitized at $11025 \mathrm{~Hz}$ and recorded to a 2 GB Compact Flash card. Recordings were made for $10 \mathrm{~s}$ every $10 \mathrm{~min}$. The recorders were moored to the wrecks at each site (about $2 \mathrm{~m}$ above the bottom).

Passive acoustic recordings were analyzed with custom software written with MATLAB (Mathworks). To characterize the goliath grouper sound, a total of 1065 individual pulses were isolated from $5 \mathrm{~d}$ of recordings using an automatic detection algorithm. This algorithm consisted of the following steps: (1) low-pass filter at $100 \mathrm{~Hz},(2)$ high-pass filter at $10 \mathrm{~Hz},(3)$ rectification of the signal, (4) smoothing of the signal with a 25 millisecond (ms) moving average, and (5) threshold detection set at $110 \mathrm{~dB}$ re: $1 \mu \mathrm{Pa}$. Once signals were identified, they were manually inspected with a spectrogram to confirm that they were goliath grouper sounds. Power spectra of individual pulses were calculated using Fast Fourier Transforms (FFT), where the number of points in the FFT was equal to the number of samples in the signal. For example, a sound $100 \mathrm{~ms}$ in duration sampled at $11025 \mathrm{~Hz}$ would consist of 1102 data points and its FFT would yield a $10 \mathrm{~Hz}$ frequency resolution. The dominant frequency (frequency with most energy) for each sound was calculated from the power spectrum of the original recorded signal without filtering. At lower signal-to-noise ratios, a significant portion of the signal can be hidden in the noise floor. Therefore, only the loudest signals $(>124 \mathrm{~dB}$ re: $\left.1 \mu \mathrm{Pa}_{\text {peak }}\right)$ were used to calculate sound duration $(\mathrm{n}=507)$.

Time series of goliath grouper sound production were analyzed by calculating band sound pressure levels in the 0 to $100 \mathrm{~Hz}$ frequency band for each 10 s recording using QLOGGER (available at www. marine.usf.edu/bio/fishlab/). The time of maximum band sound pressure level for each day was calculated for each dataset using MATLAB and presented in a histogram using $1 \mathrm{~h}$ resolution.

Acoustic telemetry with depth. Acoustic telemetry with a Vemco V13P-S256 depth coded transmitter was 
used to monitor depth movements of a fish on short time scales. The transmitter was attached to one large (approximately $2 \mathrm{~m}$ ) adult goliath grouper on September 9, 2005 and monitored through November 6, 2005 at the Dry Tortugas Site. The transmitter had a random output between 5 and $15 \mathrm{~s}$. This short output interval allowed us to detect short-duration vertical movements, such as rapid ascents. We attached the transmitter to the adult fish underwater using a speargundelivered dart tag (Floy tag BFIM-96) assuming that this method of tagging minimized stress relative to that produced by capture. The sex of the fish could not be determined. The acoustic transmitter detections were analyzed with a custom MATLAB program to determine depth and temporal distributions of detected pings. This research was conducted in accordance with institutional and national guidelines concerning the use of animals in research, and was approved by the institutional animal use and care (IACUC) committee of Florida State University (Protocol \#9902) and under a permit from the Florida Fish and Wildlife commission (FWC 05-SRP-690A).

\section{RESULTS}

\section{Goliath grouper sound description}

Goliath groupers on the wrecks produced predominantly single-pulse calls with a low dominant frequency (Fig. 1). These sounds were attributed to goliath groupers, because they were the same as sounds heard by divers approaching goliath groupers both at these sites and in shallower sites in Charlotte Harbor, Florida (J. V. Locascio \& C. C. Koenig pers. obs.). Additionally, the frequency was very low, which is consistent with sounds produced by a large fish. The dominant frequency was $60.5 \pm 9.2 \mathrm{~Hz}$ (mean $\pm \mathrm{SD}_{i} \mathrm{n}=$ 1065). The pulse duration for calls with peak received levels greater than $124 \mathrm{~dB}$ re: $1 \mu \mathrm{Pa}$ was $132.0 \pm$ $30.1 \mathrm{~ms}$ (mean $\pm \mathrm{SD} ; \mathrm{n}=507$ ). Because the distance to the fish was not known, only received levels could be measured. Of the 1065 sounds analyzed, the highest received sound level was $150.9 \mathrm{~dB}$ re: $1 \mu \mathrm{Pa}_{\text {peak }}$ and

Fig. 1. Epinephelus itajara . (A) Oscillogram (top) and spectrogram (bottom) of goliath grouper sounds. Arrow indicates individual sound indicated in (B). (B) Oscillogram (top) and power spectrum (bottom) of individual goliath grouper sound from (A). The peak sound level corresponds to $148 \mathrm{~dB}$ re: $1 \mu \mathrm{Pa}_{\text {peak }}$. The dominant frequency of this pulse is $59 \mathrm{~Hz}$. (C) Spectrogram showing multipulse and broad-band sounds attributed to goliath grouper that were produced infrequently compared to the single pulse sound
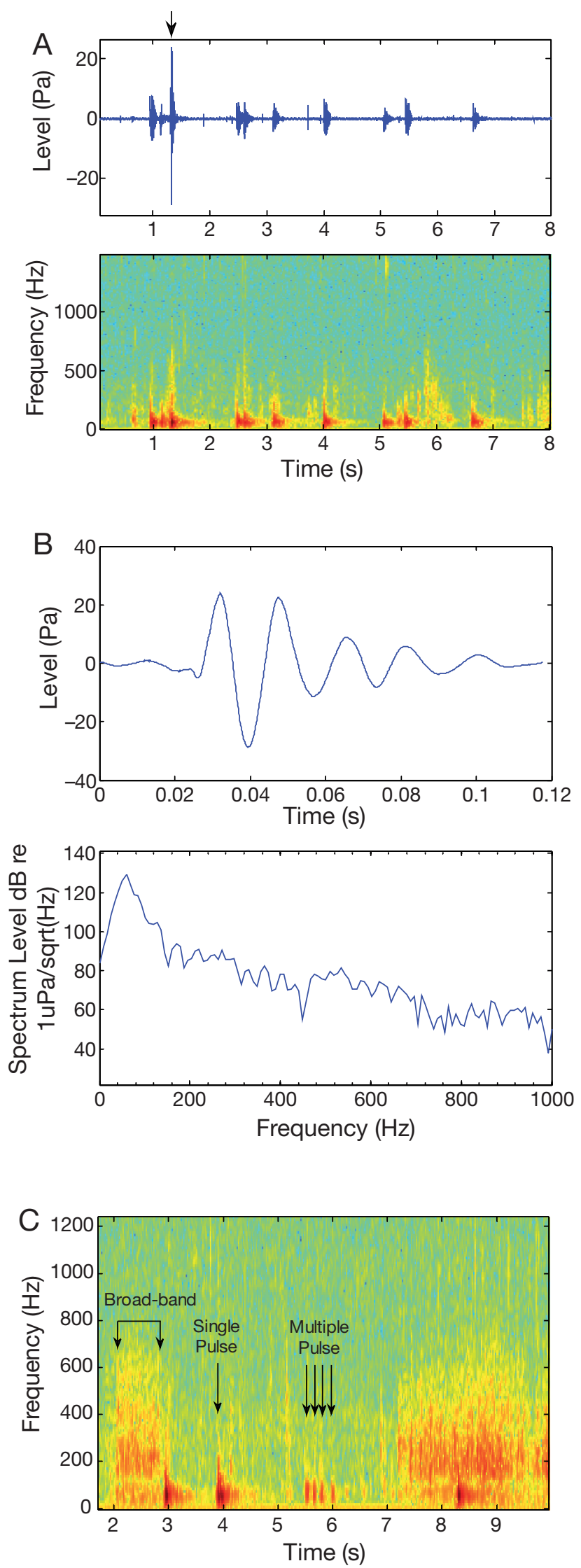
$143.8 \mathrm{~dB}$ re: $1 \mu \mathrm{Pa}_{\mathrm{rms}}$, where rms is root-mean-square. This signal has slight clipping on the recorder, so the SPL would have been approximately $3 \mathrm{~dB}$ higher based on the level of clipping. Two other sounds likely produced by goliath groupers based on their frequency are shown in Fig. 1. These sounds were infrequently produced compared to the single pulse sounds. One is a multiple pulse sound similar to that recorded by Fish \& Mowbray (1970) for goliath grouper in captivity (Fig. 1C). The other sound does not have distinctive pulses and has a broader frequency range than the other 2 sounds.

\section{Passive acoustic time series}

Since the majority of acoustic energy was below $100 \mathrm{~Hz}$, the band sound pressure level in the 0 to $100 \mathrm{~Hz}$ frequency band was used as a measurement of overall goliath grouper sound production. Calls from multiple individuals were obvious in most of the recordings, based on differences in sound level and overlap of sounds (Fig. 1). Goliath grouper sounds were loud enough to raise levels $40 \mathrm{~dB}$ above background sound levels at the Dry Tortugas Site (Fig. 2). The sound levels were lower at the Northern Site, which could be due to placement of the acoustic recorder inside the shipwreck. There were approximately 25 individual goliath grouper at the Dry Tortugas Site and approximately 40 individual goliath grouper at the Northern Site at the time of the first deployment. The maximum sound level from each night is plotted for the Northern Site data to aid in visualizing the long-term patterns of sound production (Fig. 3). Sound production was strongly diel, with

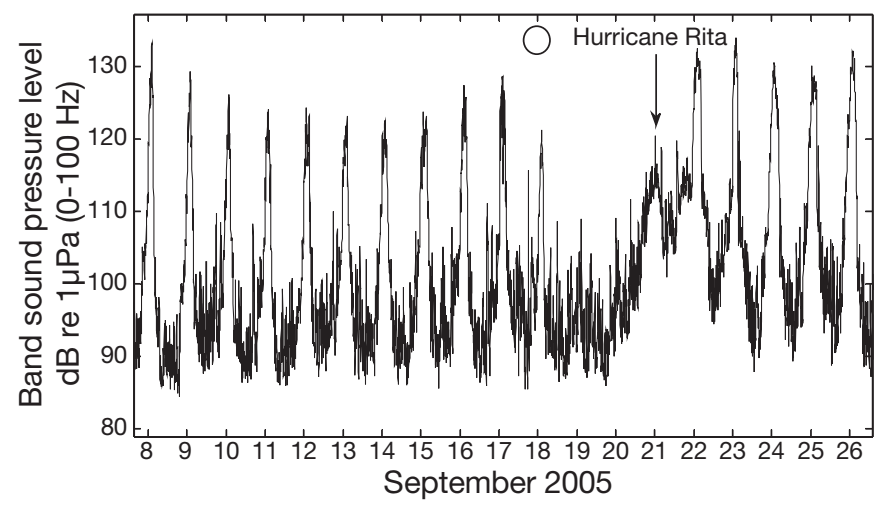

Fig. 2. Epinephelus itajara. Time series of sound production in the $0-100 \mathrm{~Hz}$ frequency band from the Dry Tortugas Site in September 2005. Data were smoothed with 6-point (1 h) moving average. The circle indicates the date of the full moon (September 18, 2005). Hurricane Rita caused an increase in the sound levels when it passed on September 21. Tick marks are located at midnight

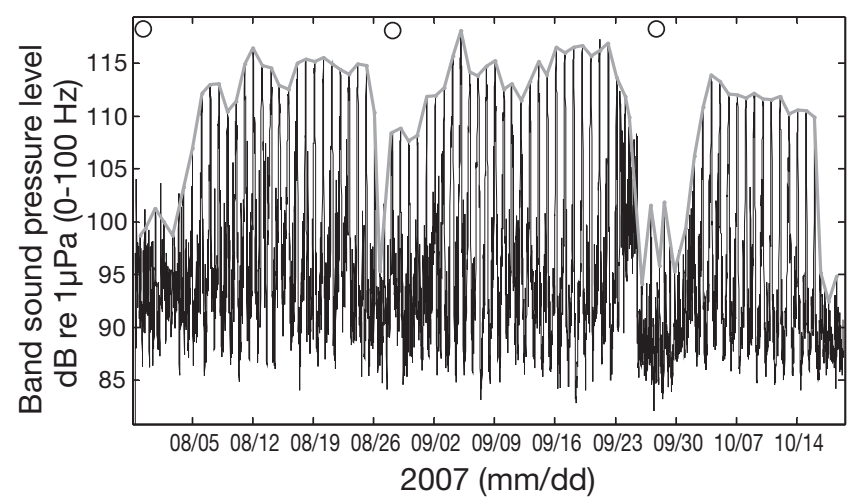

Fig. 3. Epinephelus itajara. Time series of sound production in the $0-100 \mathrm{~Hz}$ frequency band from the Northern Site from August to October 2007. Data were smoothed with 6-point $(1 \mathrm{~h})$ moving average. Circles indicate the dates of the full moon. Tick marks are located at midnight

peaks occurring between 01:00 and 02:00 $\mathrm{h}$ at the Dry Tortugas Site and between 01:00 and 04:00 at the Northern Site (Figs. 2 to 4). Each time series also showed a strong lunar periodicity in sound levels, with decreased levels of sound production on and around the full moon (Figs. 2 \& 3) for 1 to $7 \mathrm{~d}$. No strong goliath
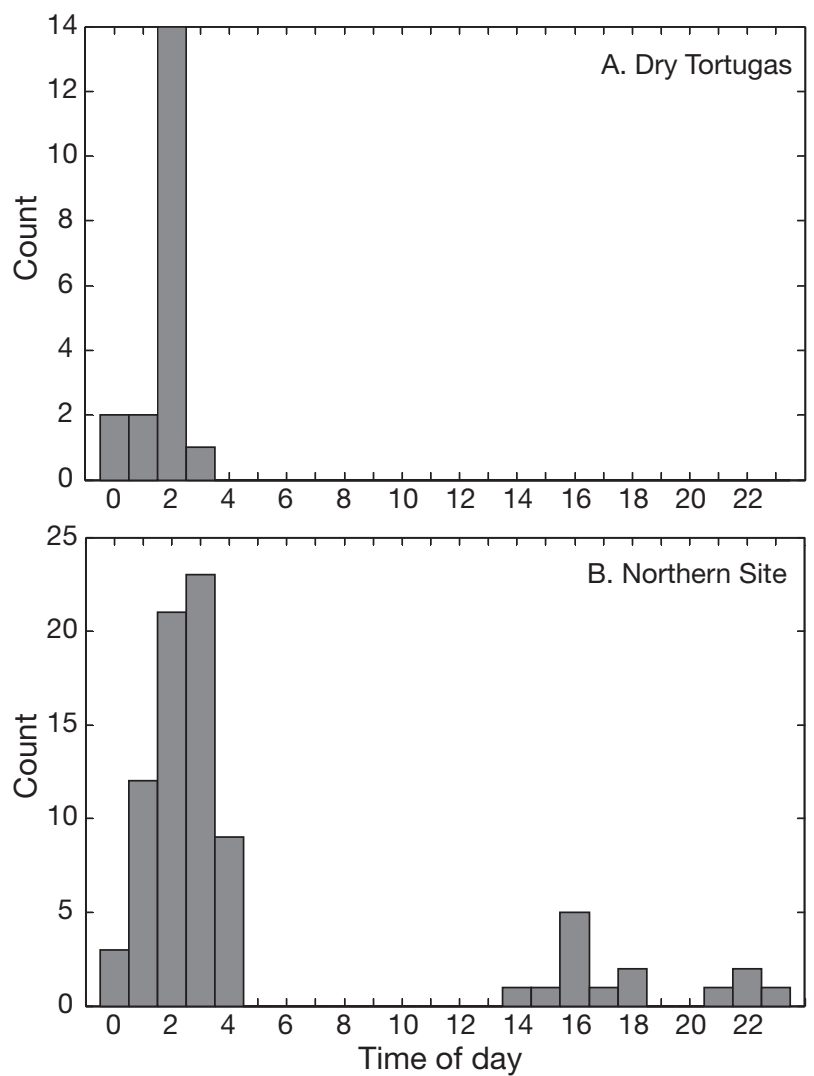

Fig. 4. Epinephelus itajara. Time of maximum sound pressure level. (A) Dry Tortugas Site. (B) Northern Site. Count: number of days in the time series that had the maximum sound level at that hour of the day 
grouper sound production (received BSPL 0 to $100 \mathrm{~Hz}$ above $95 \mathrm{~dB}$ re $1 \mu \mathrm{Pa}$ ) occurred at the Northern Site after October 16, 2007, until recording ended on December 21.

Hurricane Rita passed 38 nautical miles (n miles) south of the Dry Tortugas Site on September 20 and 21, 2005 causing an increase in low-frequency background noise, presumably due to increased sea surface state (Fig. 2). There was no apparent change in goliath grouper sound production during or after passage of the hurricane, apart from the lunar periodicity in sound production.

\section{Acoustic transmitter and depth distribution}

A total of 306282 pings were detected during the study period from the acoustic transmitter. These data were plotted as a time series of the depth of the fish (Fig. 5). With the exception of $1 \mathrm{~d}$ (October 24 to 25) the grouper was always present at the study site (Fig. 5). The majority of the time the fish was located near the bottom at depths $>40 \mathrm{~m}$ (Fig. 6), but it did make occasional short-duration forays to shallower depths (Figs. $5 \& 6$ ), the majority of which took place at night over 2 time periods, 21:00 to 00:00 $\mathrm{h}$ and 03:00 to 04:00 h (Fig. 7). Many of these forays lasted less than 2 min and can be seen as individual detections at the peaks of the forays (Fig. 5C). For example, a foray on November 3, 2005 at 01:24 h was detected at $26.6 \mathrm{~m}$. The previous detection was $60 \mathrm{~s}$ earlier at $45.7 \mathrm{~m}$, and the subsequent detection was $51.8 \mathrm{~s}$ later at $46.4 \mathrm{~m}$. Because of the resolution provided by the received transmissions, the actual ascent rate could have been faster and possibly to a shallower depth.

\section{DISCUSSION}

Goliath grouper were prolific producers of singlepulse low-frequency (60 Hz) sounds. The mechanism of sound production is likely to be similar to that for Nassau grouper, which involves contraction of a sonic muscle that is connected to the vertebrae and swimbladder (Hazlett \& Winn 1962). Based on the structure of the waveform, which begins with a rapid onset followed by a rapid decay (Fig. 1B), the swimbladder system appears to be highly damped, like that of the toadfish (Fine et al. 2001). There is often an inverse relationship between size and dominant frequency (Myrberg et al. 1993, Lobel \& Mann 1995) of fish calls, and goliath grouper sounds are among the lowest frequency fish sounds that have been recorded to date.

Sound production occurred on a diel basis, with the highest levels between 01:00 and 03:00 h. This pattern was consistent between the 2 separate aggregation sites, with recordings made 2 yr apart. There was also a strong lunar pattern at both sites, with reduced sound production around the full moon. Recordings were made at both aggregation sites during the peak of the spawning season and show high levels of sound production nightly, resembling patterns documented for sciaenids (Locascio \& Mann 2005, 2008), except that they tended to be later in the night than most sciaenid species.

The acoustic telemetry data, while limited to 1 ind., showed that the fish was resident at the aggregation site for 2 mo (the duration of the record), traveling out of the range of the receiver for less than $1 \mathrm{~d}$. Goliath groupers show strong site fidelity in both the adult and juvenile stages (Koenig et al. 2007, C. C. Koenig unpubl. data). This is consistent with what was seen in another study in which 2 goliath groupers were tagged, and were resident for the duration that they were tagged, 1 tag staying on for $73 \mathrm{~d}$, the other less (Domeier et al. 2006). The purpose of using the depthencoded tag was to attempt to document spawning ascents that have been observed in other reef fish species (Colin \& Clavijo 1988). Thus, the ping rate was set high to capture such events. A number of ascents were detected in the depth record, with the majority occurring near midnight and 03:00 $\mathrm{h}$. The forays at 03:00 $\mathrm{h}$ occurred just after peaks in sound production. This is in contrast to the results of Domeier et al. (2006), who found ascents at sunrise in 2 tagged goliath groupers.

The eye of hurricane Rita passed $38 \mathrm{n}$ miles south of the Dry Tortugas Site on September 21, 2005. While the acoustic signature of the hurricane was detected, there was no apparent effect on patterns of sound production or fish movement. Two days prior to the hurricane, grouper sound levels had decreased; however, this appears to have been related to the lunar cycle of sound production. The lack of a response to Rita is similar to what was seen for Hurricane Charley in Charlotte Harbor, Florida and its effects on sciaenid sound production, where fish continued their nightly chorus unabated after the hurricane (Locascio \& Mann 2005).

Our ultimate goal is to determine when goliath grouper are spawning, so that spawning data can be used in physical oceanographic models to predict larval transport and recruitment patterns. The excursions recorded with the acoustic telemetry could represent spawning ascents. This is supported by their high amplitude and short duration. To confirm this will require video observation and plankton sampling for eggs. The combination of the passive acoustic data and transmitter depth data suggest that spawning occurs sometime between midnight and 03:00 h.

If night-time spawning is occurring, it is possible that it is an adaptation to avoid egg predation (Holt et al. 

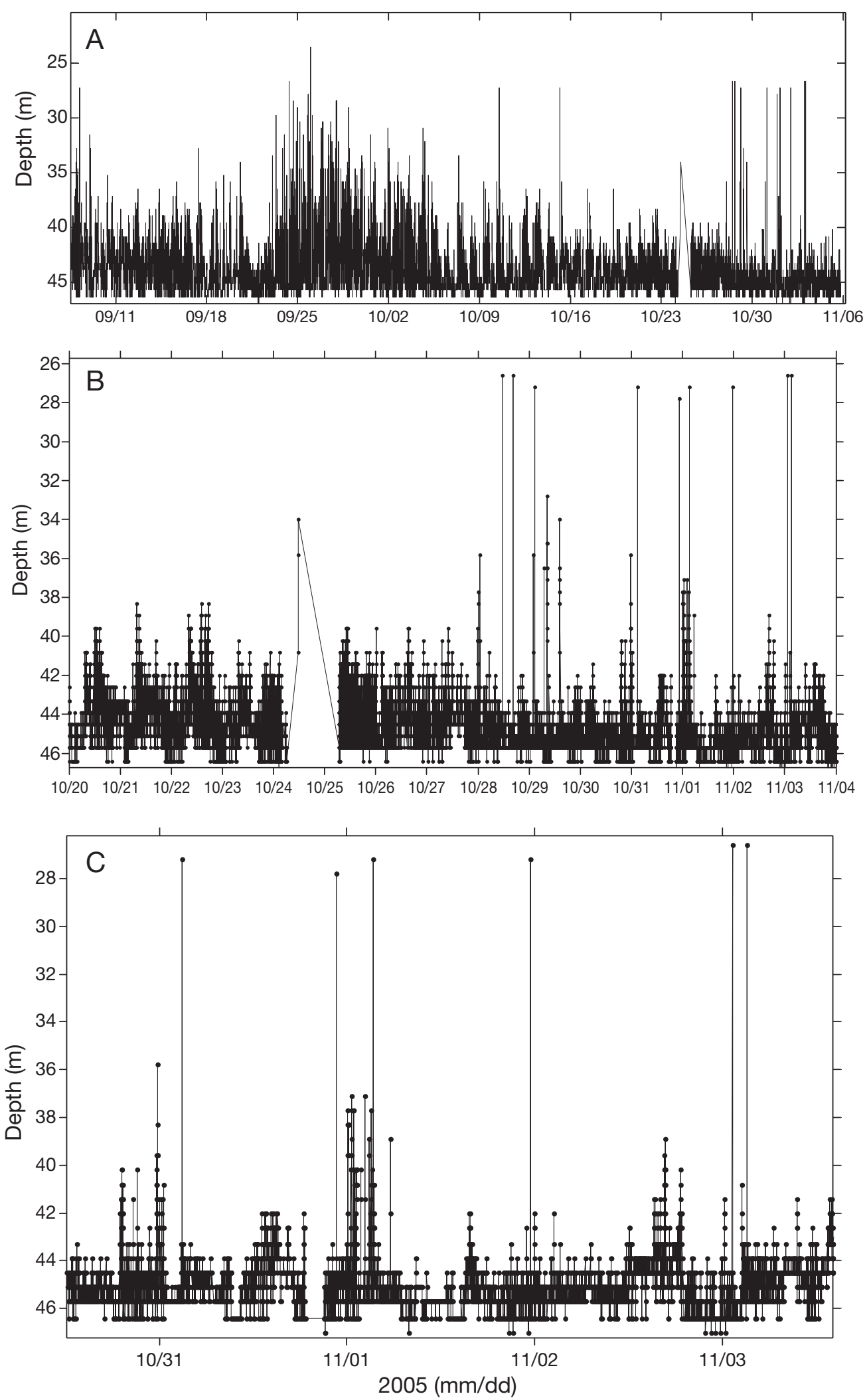

Fig. 5. Epinephelus itajara. Time series of goliath grouper depth recorded with a depth-coded acoustic transmitter. (A) Entire time series. (B) Expanded view of 2.5 d. Dots indicate depths where pings were received. (C) Expanded view showing a foray to $24 \mathrm{~m}$ depth 


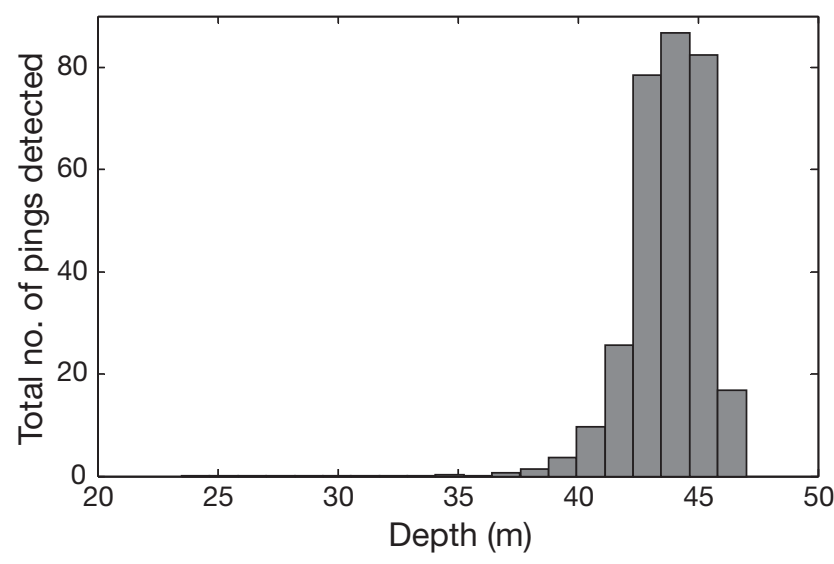

Fig. 6. Epinephelus itajara. Depth distribution recorded with acoustic transmitter tag. The majority of pings were detected with the fish near the bottom at $46 \mathrm{~m}$ depth

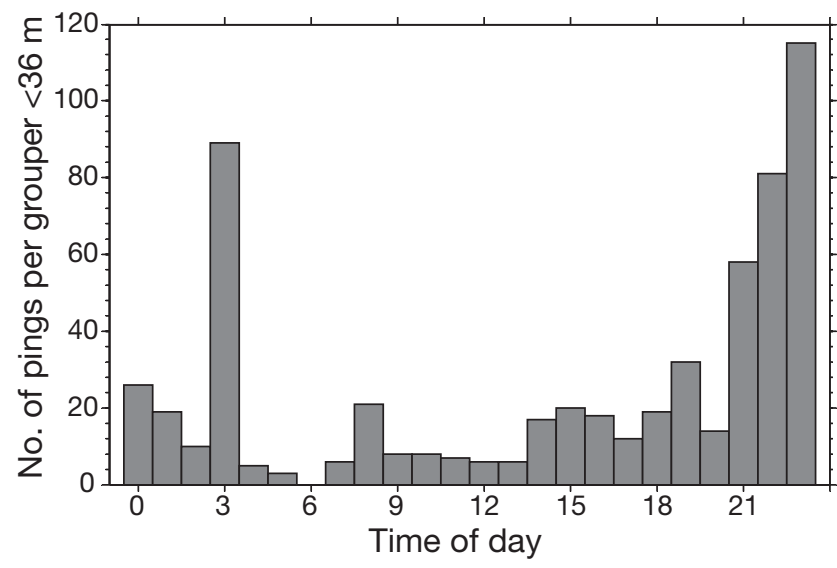

Fig. 7. Epinephelus itajara. Time of day when depths from acoustic transmitter implanted in goliath grouper were $<36 \mathrm{~m}$

1985). Goliath grouper aggregation sites have abundant populations of potential egg predators such as round scad Decapterus punctatus, round herring Etrumeus teres and other small schooling carangids and clupeids (C. C. Koenig unpubl. data). Because these plankton feeders are visual predators, night-time spawning, especially on dark nights, could effectively minimize their impact on reproductive output.

The passive acoustic data time series are also useful in that they show goliath grouper to be prolific sound producers on aggregation sites. This means that this species shows promise for large spatial scale passive acoustic mapping of aggregation sites. This could be accomplished with in situ acoustic recorders, as used in this study, or hydrophones towed from vessels or onboard autonomous underwater vehicles, such as gliders. Another potential application is to use passive acoustics to estimate population density. However, to do so we need several pieces of information that we currently do not have, including how often goliath grouper vocalize and over what distance their sounds can be detected. This involves measuring sound source levels, acoustic propagation loss, and background noise levels.

Goliath grouper are listed as critically endangered on the International Union for Conservation of Nature Red List, although their populations in the southeastern USA have recently shown some signs of recovery after institution of a fishing moratorium in the early 1990s (Chan Tak-Chuen \& Padovani Ferreira 2006). Our results suggest that a combination of active and passive acoustic methods can be used to track fish movement and behavior at aggregation sites and to monitor spawning activity at these sites using sound production as a proxy. These types of studies can augment traditional studies and allow mapping of goliath grouper aggregation sites over large spatial areas at relatively low cost. Passive acoustics can be used to gain knowledge of goliath grouper spawning aggregations and aid in their conservation and management through long-term monitoring, which would otherwise be difficult given their location relatively far from shore.

Acknowledgements. We thank D. DeMaria for guiding us to presumed spawning sites of goliath grouper, in situ tagging with the acoustic transmitter, and for retrieving the acoustic receivers. We gratefully acknowledge NOAA MARFIN funding (grant number A05NMF4540045) to C.C.K. and F.C.C.

\section{LITERATURE CITED}

Amorim MCP (2006) Diversity of sound production in fish. In: Ladich F, Collin SP, Moller P, Kapoor BG (eds) Communication in fishes. Science Publishers, Enfield, $\mathrm{NH}$, p 71-105

Bullock LH, Murphy MD, Godcharles MF, Mitchell ME (1992) Age, growth, and reproduction of jewfish Epinephelus itajara in the eastern Gulf of Mexico. Fish Bull (Wash DC) 90:243-249

Chan Tak-Chuen T, Padovani Ferreira B (2006) Epinephelus itajara. In: 2007 IUCN Red List of Threatened Species. www.iucnredlist.org/search/details.php/7857/all

Colin PL (1990) Preliminary investigations of reproductive activity of the jewfish, Epinephelus itajara (Pisces: Serranidae). Proc 43rd Gulf Caribbean Fish Inst, p 138-147

Colin PL, Clavijo IE (1988) Spawning activity of fishes producing pelagic eggs on a shelf-edge coral reef, southwestern Puerto Rico. Bull Mar Sci 43:249-279

Connaughton MA, Taylor MH (1995) Seasonal and daily cycles in sound production associated with spawning in the weakfish, Cynoscion regalis. Environ Biol Fishes 42: 233-240

Domeier ML, DeMaria D, Nasby-Lucas N (2006) Behavior and habitat use of goliath grouper (Epinephelus itajara) based upon acoustic telemetry. Proc 10th Int Coral Reef Symp, p 1314-1325

Fine ML, Malloy KL, King CB, Mitchell SL, Cameron TM 
(2001) Movement and sound generation by the toadfish swimbladder. J Comp Physiol A 187:371-379

Fish MP, Mowbray WH (1970) Sounds of western North Atlantic fishes. Johns Hopkins Press, Baltimore, MD

Gilmore RG Jr (2003) Sound production and communication in the spotted seatrout. In: Bortone S (ed) Biology of the spotted seatrout. CRC Press, Boca Raton, FL, p 177-195

Hazlett B, Winn HE (1962) Sound producing mechanism of the Nassau grouper, Epinephelus striatus. Copeia 2: $447-449$

Holt GJ, Holt SA, Arnold CR (1985) Diel periodicity of spawning in sciaenids. Mar Ecol Prog Ser 27:1-7

Hood P, Crabtree R, Murphy M (1999) Preliminary investigations of red drum spawning habitat in Tampa Bay, Florida. Florida Marine Research Institute. Abstract from Florida Chapter Am Fish Soc 19th Annual Meeting, Brooksville, FL

Koenig CC, Coleman FC, Eklund AM, Schull J, Ueland J (2007) Mangroves as essential nursery habitat for goliath grouper (Epinephelus itajara). Bull Mar Sci 80:567-586

Ladich F, Myrberg AA Jr (2006) Agonistic behavior and acoustical communication. In: Ladich F, Collin SP, Moller P, Kapoor BG (eds) Communication in fishes, Vol 1. Science Publishers, Enfield, NH, p 121-148

Lobel PS (1992) Sounds produced by spawning fish. Environ Biol Fishes 33:351-358

Lobel PS, Mann DA (1995) Spawning sounds of the damselfish Dascyllus albisella (Pomacentridae) and relationship to male size. Bioacoustics 6:187-198

Locascio JV, Mann DA (2005) Effects of Hurricane Charley on fish chorusing. R Soc Biol Lett 1:362-365

Locascio JV, Mann DA (2008) Diel periodicity of fish sound

Editorial responsibility: Kevin Rhodes,

Hilo, Hawaii, USA production in Charlotte Harbor, Florida. Trans Am Fish Soc 137:606-615

Mann DA, Lobel PS (1995) Passive acoustic detection of sounds produced by the damselfish, Dascyllus albisella (Pomacentridae). Bioacoustics 6:199-213

Mok HK, Gilmore RG (1983) Analysis of sound production in estuarine fish aggregations of Pogonias cromis, Bairdiella chrysoura, and Cynoscion nebulosus (Sciaenidae). Bull Zool Inst Acad Sinica 22:157-186

Myrberg AA Jr, Ha SJ, Shamblott MJ (1993) The sounds of bicolor damselfish (Pomacentrus partitus): predictors of body size and a spectral basis for individual recognition and assessment. J Acoust Soc Am 94:3067-3070

Sadovy Y (1994) Grouper stocks of the western central Atlantic: the need for management and management needs. Proc 43rd Ann Gulf Carribbean Fish Inst Meeting, Charleston, p 43-64

Sadovy Y, Eklund AM (1999) Synopsis of biological information on the Nassau grouper, Epinephelus striatus, (Bloch 1792), and the jewfish, E. itajara (Lichtenstein 1822). US Dept. of Commerce, Seattle, WA, NOAA Tech Rep, NMFS 146, FAO Fish Synopsis 157

Saucier MH, Baltz DM, Roumillat WA (1992) Hydrophone identification of spawning sites of spotted seatrout Cynoscion nebulosus (Osteichthyes: Sciaenidae) near Charleston, South Carolina. NE Gulf Sci 12:141-145

SEDAR6 (Southeast Data Assessment and Review) (2004) Complete stock assessment report of SEDAR 6 goliath grouper. Assessment Report 1. SEDAR6-SAR1, Charleston, SC

Tavolga WN (1977) Sound production and detection. In: Tavolga WN (ed) Sound production in fishes. Dowden, Hutchinson, and Ross, Stroudsburg, PA

Submitted: February 19, 2008; Accepted: May 28, 2008 Proofs received from author(s): September 16, 2008 